Article

\title{
Sustainable and Stable Clay Sand Liners over Time
}

\author{
Ahmed M. Al-Mahbashi *, Muawia Dafalla (1), Abdullah Shaker and Mosleh A. Al-Shamrani \\ Bugshan Research Chair in Expansive Soils, Deparment of Civil Engineering, College of Engineering, \\ King Saud University, Riyadh 11421, Saudi Arabia; mdafalla@ksu.edu.sa (M.D.); ashaker@ksu.edu.sa (A.S.); \\ shamrani@ksu.edu.sa (M.A.A.-S.) \\ * Correspondence: aalmahbashi@ksu.edu.sa
}

Citation: Al-Mahbashi, A.M.;

Dafalla, M.; Shaker, A.; Al-Shamrani,

M.A. Sustainable and Stable Clay

Sand Liners over Time. Sustainability

2021, 13, 7840. https://doi.org/

$10.3390 /$ su13147840

Academic Editor: Muhammad

Junaid Munir

Received: 24 May 2021

Accepted: 9 July 2021

Published: 13 July 2021

Publisher's Note: MDPI stays neutral with regard to jurisdictional claims in published maps and institutional affiliations.

Copyright: (C) 2021 by the authors Licensee MDPI, Basel, Switzerland. This article is an open access article distributed under the terms and conditions of the Creative Commons Attribution (CC BY) license (https:// creativecommons.org/licenses/by/ $4.0 /)$.
Abstract: The washout of fine materials from liners consisting of clay-sand mixtures is expected to influence the hydraulic conductivity. Clay sand liners must be assessed for efficiency when initially subjected to flood or standing water as the wetting under a hydraulic gradient can cause fine material to move and migrate away from the mixture. During wetting and drying complex expansion and shrinkage, changes take place. These changes affect the hydraulic conductivity and are likely to go out of the design range set out for the facility. The research covers the behavior of two clay sand liners tested over an extended time. The hydraulic conductivity measured under a specific hydraulic gradient was measured continuously following the establishment of the test set-up. Self-recording sensors were used to measure the temperature during the tests. The results indicated that the hydraulic conductivity reduces after an initial period of increase and fluctuation caused by the loss of mass because of fine material migration and swelling initiated due to the high content of smectite minerals. The testing and monitoring continued for more than 400 days. The permanent reduction in the hydraulic conductivity occurs after the initial period of repeated rise and fall. The extent of the initial period for the two tested mixtures is subject to the fine content mass and the clay mineralogy. The continuous reduction in the hydraulic conductivity after the initial period is due to the rearrangement of particles and compression in the sand-clay mixture.

Keywords: sand-clay liners; hydraulic conductivity; flow; sustainability; lifetime

\section{Introduction}

Sand-clay and sand-bentonite mixtures have been widely studied in the literature as they are linked to the waste control barriers and liner systems used in various industries [1-7]. During the lifetime of liner layers, the efficiency of these layers should satisfy the design criteria of the hydraulic conductivity, and most of these layers are assumed to be designed for a considered period of years. Field evaluations of the changes in hydraulic conductivity are difficult and time-consuming and cannot be generalized for mixtures subjected to different exposure conditions. The time required to run a hydraulic conductivity test for clay materials is long and depends on the state of compaction and clay mineralogy. Sand-clay mixtures are more porous and can achieve a steady flow in a shorter time. The performance evaluation of sand-clay liners after construction is not common in practice and very few published articles are available in the literature. The studies of Abdolahzadeh et al. [8] confirmed that for a cover seepage-control layer, the flow rate decreases with time. They assumed that the settlement in the layer influenced the saturated permeability from the four years of observation data used.

The works of Chapuis [2,9] called for using empirical formulae to predict the hydraulic conductivity based on clay content, porosity, and the degree of saturation. The stability of fines within the mixtures and time-dependent changes are important factors that were ignored in most hydraulic conductivity studies. Belkhatir et al. [10] indicated that fines percent or mass of fines has a key role in the hydraulic conductivity of sand mixtures and 
can reduce its value by four times. Most of the studies conducted did not check the stability of these fines during long-term measurements.

A network of large pores can be formed when the clay is subjected to frequent wetting and drying. Wang et al. [11] stated that the soil hydraulic conductivity changes are related to the large-pore quantity formation during the hydration process.

For this reason, we decided to run trials in the laboratory to enhance a prediction system based on the hydraulic conductivity changes when specific parameters are altered. The main concept of this study is to introduce a new approach for the assessment of serviceability and lifetime of sand-clay liners. This assessment is based on subjecting a sand-clay liner to a hydraulic gradient for an extended period. In reality, the hydraulic gradient imposed due to floods or standing water lasts for a short period of time, normally a few hours or few days. The overall cumulative exposure time in which a sand-clay liner is subjected to water flow can be computed based on the exposure time for each season. The degradation of the sand-clay mixture and loss of fines can reduce the hydraulic conductivity to values under the specified level. Works of Al-Mahbashi and Dafalla [12] addressed the mass loss occurring when a sand-clay mixture is subjected to a hydraulic gradient over an extended period.

\section{Materials and Methods}

\subsection{General}

The clay sand liner considered in this study consists of a local highly plastic clay added to a poorly graded fine to medium sand. The coefficient of concavity for sand is 0.945 and the uniformity coefficient is 1.713 . This is leading to a poorly graded classification following ASTM D2487 [13]. The local clay was obtained from the eastern province of Saudi Arabia, specifically, from Al-Qatif city. The montmorillonite content for this clay is in the range of $3 \%$ to $23 \%$ and the palygorskite is in the range of $5 \%$ to $33 \%$ [14]. This clay is classified as $\mathrm{CH}$ with moderate to high expansion potential [15-18]. Table 1 presents the geotechnical characterization of Al-Qatif clay. The chemical composition of Al-Qatif clay is presented in Table 2. The $\mathrm{pH}$ and cation exchange capacity parameters of this expansive clay are estimated to be about 7.6 and 55.80 (meq/100 gm) [16,19]. For comparison purposes, a $15 \%$ bentonite sand mixture is to be subjected to tests similar to the local clay. The basic properties of used bentonite have been presented in Table 3.

Table 1. Soil Characterization for Al-Qatif Soil.

\begin{tabular}{cc}
\hline Property & Value \\
\hline Specific gravity, Gs & 2.72 \\
Liquid limit, wL (\%) & $160 \%$ \\
Plastic limit, wP (\%) & $60 \%$ \\
Shrinkage limit, wsh (\%) & $12 \%$ \\
\% passing sieve no. 200 & $65-95 \%$ \\
Unified soil classification & $\mathrm{CH}$ \\
Maximum dry unit weight (kN/ $\mathrm{m}^{3}$ ) & 12 \\
Optimum water content (\%) & $38 \%$ \\
Swelling potential (ASTM D4546) & $16-26 \%$ \\
Swelling pressure, $\mathrm{kN} / \mathrm{m}^{2}$ (ASTM D4546) & $550-600$ \\
\hline
\end{tabular}

Table 2. Chemical composition for Al-Qatif Soil.

\begin{tabular}{|c|c|c|c|c|c|c|c|}
\hline $\mathrm{K}^{+}(\%)$ & $\mathrm{K}_{2} \mathrm{O}(\%)$ & Al (\%) & $\mathrm{Al}_{2} \mathrm{O}_{3}(\%)$ & Si (\%) & $\mathrm{SiO}_{2}(\%)$ & $\mathrm{Ca}^{2+}(\%)$ & $\mathrm{CaO}(\%)$ \\
\hline 1.8 & 2.2 & 3.3 & 6.3 & 8.1 & 17.3 & 0.7 & 0.9 \\
\hline
\end{tabular}


Table 3. Typical physical properties of bentonite.

\begin{tabular}{cc}
\hline Property & Value \\
\hline Specific gravity, GS & 2.65 \\
Liquid limit, LL (\%) & 480 \\
Plastic limit, PL (\%) & 50 \\
Plasticity index, PI (\%) & 430 \\
\hline
\end{tabular}

\subsection{Grain Size Analysis}

The clay obtained from Al-Qatif is rich in fines (material passing sieve no. 200) and measured as $76 \%$, as indicated in Figure 1 . Figure 1 presents the hydrometer analysis as part of gradation analysis conducted following ASTM D7928 [20]. The fine material in the sand-clay mixtures measured before conducting the hydraulic conductivity test was $11 \%$ and $15 \%$ for mixtures with $15 \%$ and $20 \%$ clay content. The values reported here represent the weight of fine material after wet sieving through sieve no. 200 and then oven drying.

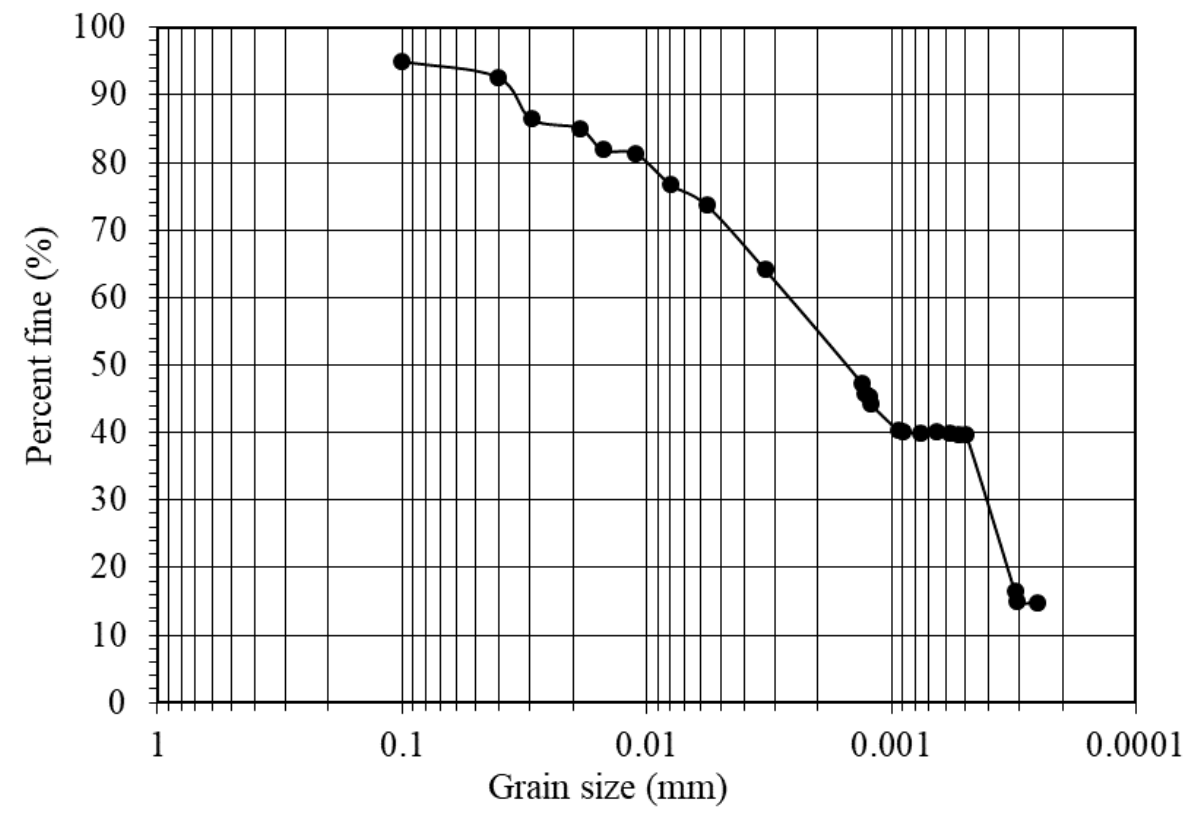

Figure 1. Hydrometer analysis of Al-Qatif clay.

\subsection{Density of Samples}

The samples prepared for the hydraulic conductivity tests were statically compacted to achieve the maximum dry density (MDD) and optimum water content (OWC) values as shown in the compaction test conducted following ASTM D698 [21]. The maximum dry density (MDD) and the optimum water content (OWC) values for $15 \%$ and $20 \%$ clay content mixtures were 17.76 and $18.30 \mathrm{kN} / \mathrm{m}^{3}$ for the maximum dry density; $14 \%$ and $15.5 \%$ for the optimum moisture content, respectively.

\subsection{Hydraulic Conductivity from Falling Head}

A hydraulic conductivity cell $80 \mathrm{~mm}$ in diameter and $30 \mathrm{~mm}$ in thickness was used to perform the falling head hydraulic conductivity tests. The sand-clay mixtures were statically compacted to the maximum dry density and optimum moisture content inside the hydraulic conductivity cell. Wire mesh and porous stones were placed on the top and bottom of the soil specimen. To include the effect of primary expansion, all specimens were inundated under a slight surcharge load (7 to $30 \mathrm{kPa}$ ) for 5 to 7 days. Distilled water was used in the inundation. LCD transducer connected to a data logger was used to record vertical displacement. When the vertical displacement transducer shows no change over $24 \mathrm{~h}$ the sample is considered ready for the test. The falling head hydraulic conductivity 
test method was performed following ASTM D5856 [22] standard. When 4 successive measurements of the flow are within a small difference then the flow is considered steady. When the steady flow was established and the hydraulic conductivity was attained, a continuous flow was then allowed on the soil specimen through an elevated tank at a surcharge of pressure $7 \mathrm{kPa}$. The time and the amount of outflow water were recorded and the rate of outflow was calculated. The hydraulic conductivity measurements were conducted 1-3 times per day during the discharge or flow by closing the flow valve and using a graduated burette connected at the same outflow level of the tank. The records of outflow rate and hydraulic conductivity were performed continuously for an extended period. The test duration was considered for an initial period of 60 to 100 days in the first stage and then a longer stage continued up to 400 days. Figure 2 presents the setup of the hydraulic conductivity testing unit used.

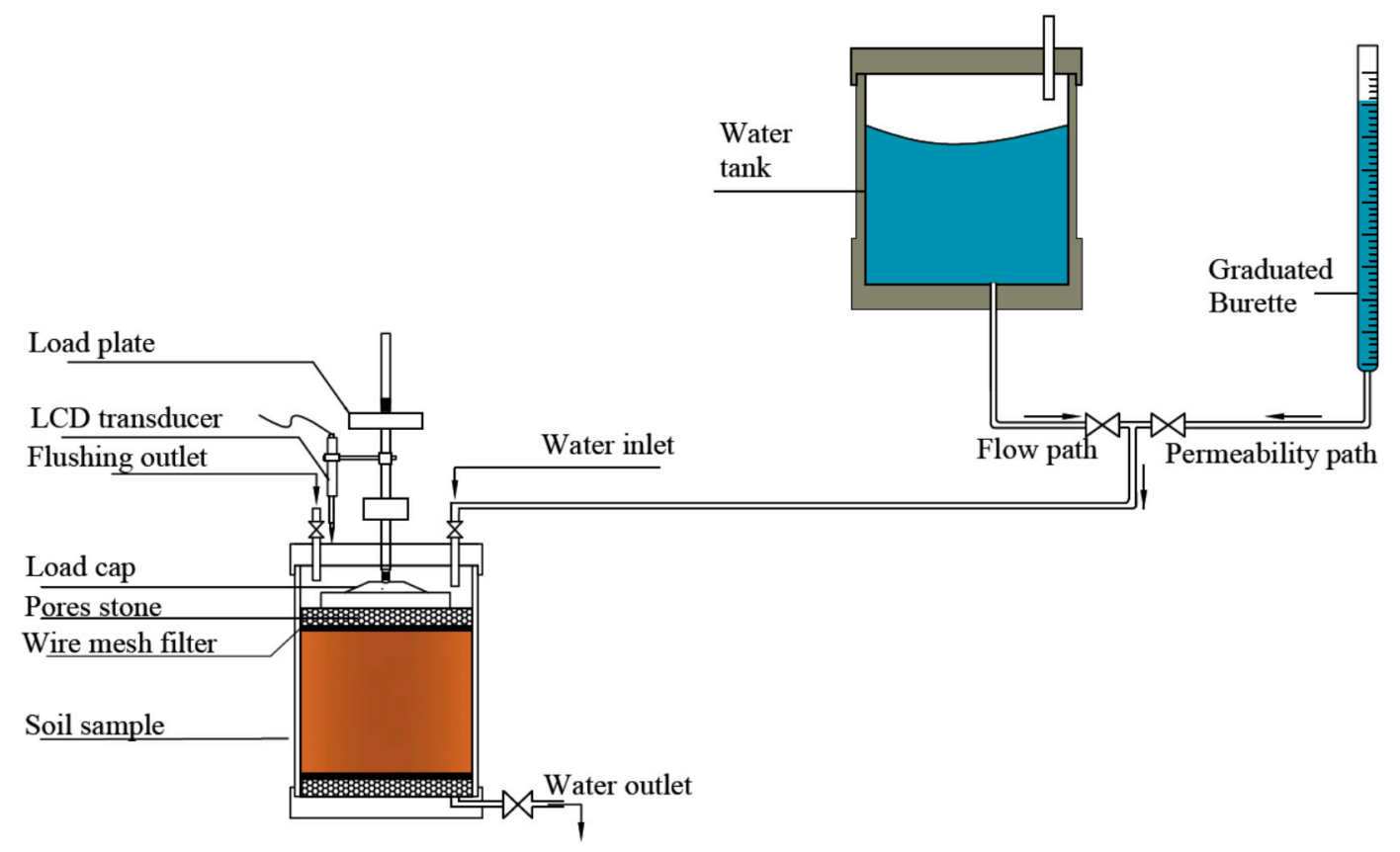

Figure 2. Schematic diagram of the testing setup.

\subsection{Mass of Fines within the Mixtures}

To investigate the mass stability and degradation due to loss of fines during extended hydraulic conductivity tests, the percent of fines (material finer than $75 \mu \mathrm{m}$ ) in each sample was determined before and after the test. For this purpose, two identical specimens were prepared for each mixture, the fine percent for the first specimen was determined before starting the long-run hydraulic conductivity test. The second one used in the long-run hydraulic conductivity testing was checked for fines content by the end of the test. The test was conducted in the laboratory by soaking the specimen in a distilled water and then mixed thoroughly. Then sieved through the no. 200 sieve by washing as described in ASTM D1140 [23]. The dry weight of the fine material was determined after oven drying and expressed as fine percentage by dry weight.

\section{Results}

This study covered the use of clay content of $15 \%$ and $20 \%$ clay content. The choice of these two concentrations is based on the work of Dafalla [7] in which he stated that $15 \%$ clay content is sufficient to achieve a hydraulic conductivity of $\left(10^{-7} \mathrm{~cm} / \mathrm{s}\right)$ which is normally recommended for the sand-clay liners. The $15 \%$ commercial bentonite was also tested for comparison purposes. 
The hydraulic conductivity of the mixtures was tested in the first stage, for a period continued to 100 days. This stage covered three types of mixtures: 15\% Al-Qatif clay, 20\% Al-Qatif clay, and 15\% Bentonite clay. Observations of the changes during the first stage are presented by Al-Mahbashi and Dafalla [12]. These observations indicated cycles of rising and falling for all mixtures for the first 100 days. The work presented here covers a further period extending to 400 days and is referred to as stage 2. Not all mixtures were subjected to second-stage testing. Only the $20 \%$ Al-Qatif clay mixture and the $15 \%$ bentonite clay were included in stage 2 . The main parameters examined are the hydraulic conductivity, the fines content, the ambient temperature, and the vertical applied stress.

\subsection{Hydraulic Conductivity}

The hydraulic conductivity beyond 100 days indicated a continuous drop for the $15 \%$ and $20 \%$ clay content regardless of the applied vertical stress. This drop is attributed to the skeleton collapse and change of the fabric structure following the loss of fine clay particles with the continuous flow; many researchers linked the formation damage to the fines migration [24-26].

Marot et al. [27] also reported reduction of hydraulic conductivity due to erosion of fines and redeposion of sand particles. When the clay paste within the voids swell, cotton-like soft material is formed. This material is very easy to wash out along with the flowing water. As the penetration of moisture into the clay paste takes some time, further swelling will be initiated by inner particles from the clay core. This can explain the frequent occurrence of increases and decrease in the hydraulic conductivity values. The fluctuation of these values takes place within short intervals of time. The overall trend remains as a continuous drop in the hydraulic conductivity.

The drop of the hydraulic conductivity value $(\mathrm{k})$ from $5.8 \times 10^{-8}$ to $2.0 \times 10^{-8}$ is observed over the period from 100 to 450 days for the mixture with $15 \%$ bentonite clay (Figure 3). The drop of the hydraulic conductivity value (k) from $7.5 \times 10^{-7}$ to $2.8 \times 10^{-7}$ is observed over the period from 100 days to 450 days for the mixture with $20 \%$ Al-Qatif clay under a surcharge of $30 \mathrm{kPa}$ (Figure 4). For a surcharge of $7 \mathrm{kPa}$, the hydraulic conductivity value $(\mathrm{k})$ remained within a small range of $2.5 \times 10^{-6}$ to $1.5 \times 10^{-6}$ in a period of 50 to 150 days for the mixtures with $20 \%$ and $15 \%$ clay respectively as shown in Figures 5 and 6.

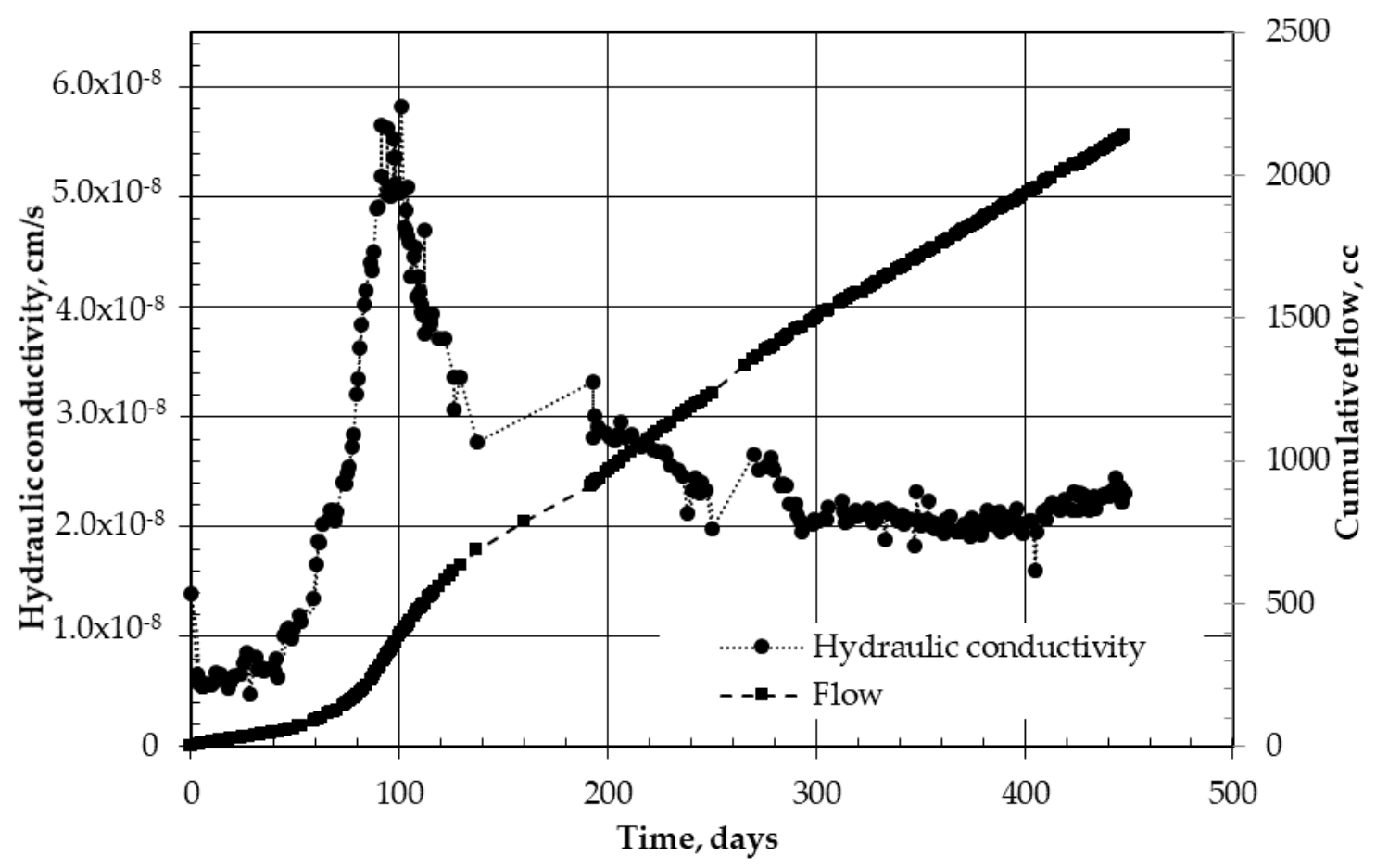

Figure 3. The hydraulic conductivity and cumulative flow versus time in days for $15 \%$ bentonite mixture under $7 \mathrm{kPa}$ stress. 


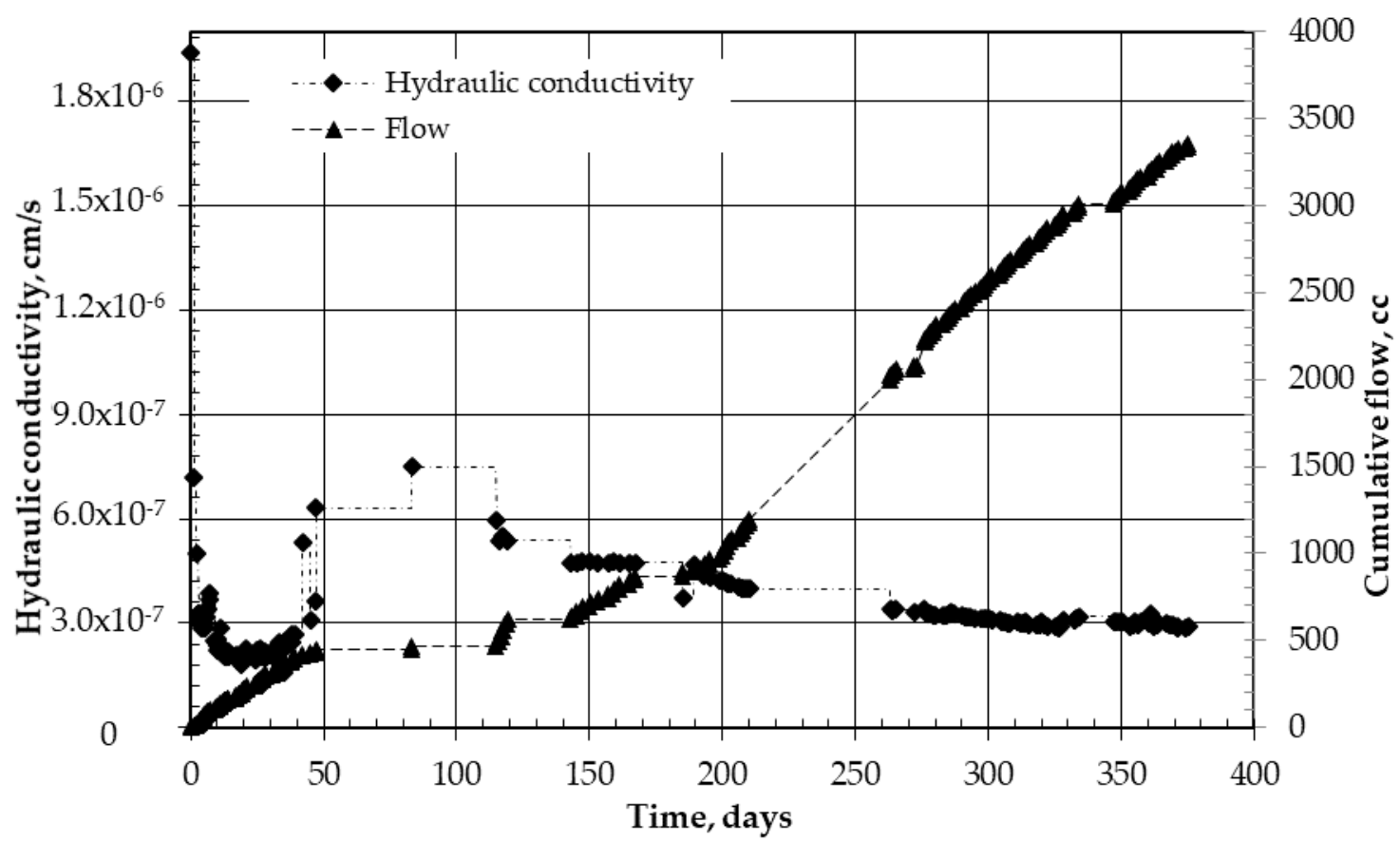

Figure 4. The hydraulic conductivity and cumulatice flow versus time in days for $20 \% \mathrm{Al}$-Qatif clay mixture under $30 \mathrm{kPa}$ stress.

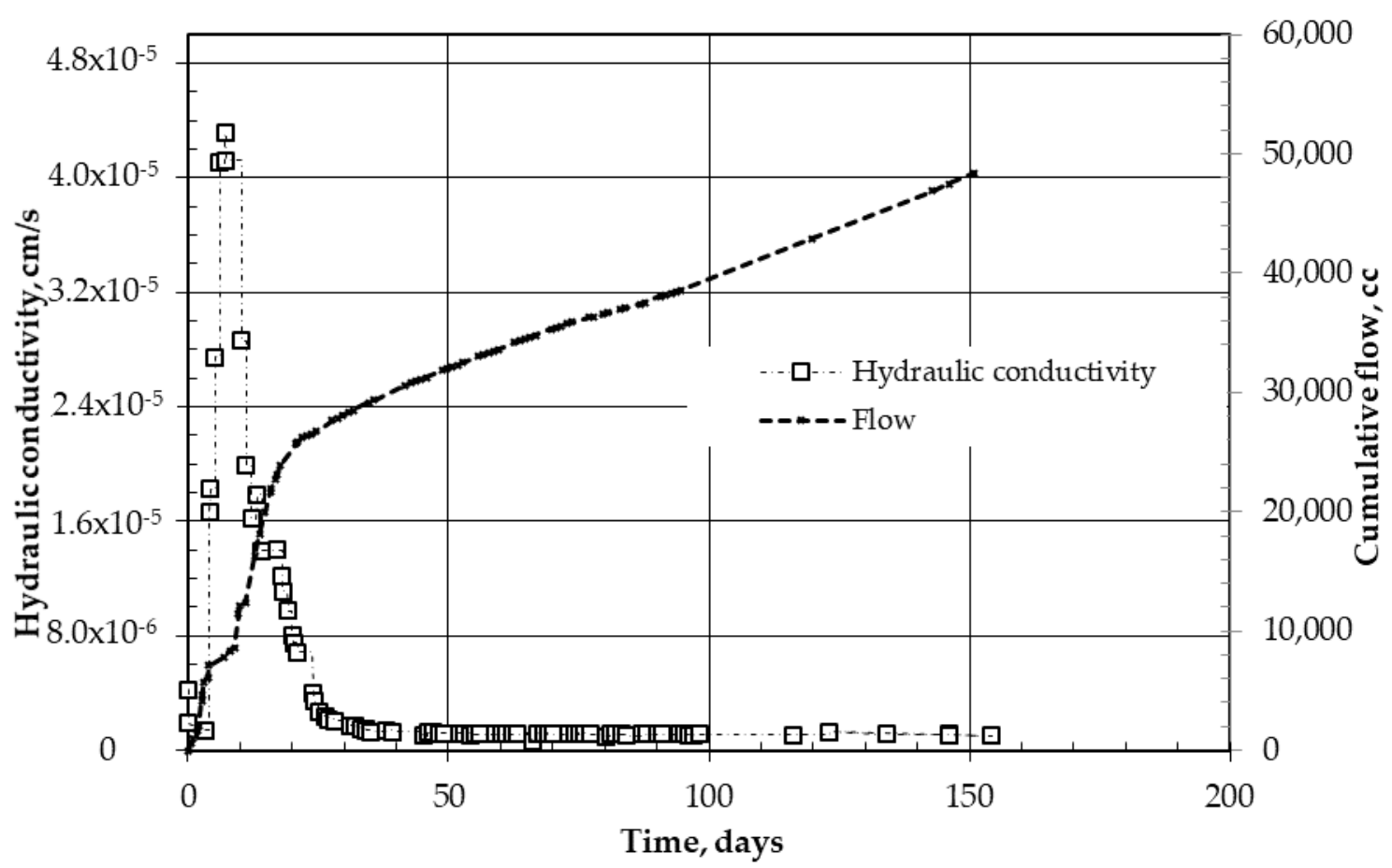

Figure 5. The hydraulic conductivity and cumulative flow versus time in days for 20\% Al-Qatif clay mixture under $7 \mathrm{kPa}$ stress. 


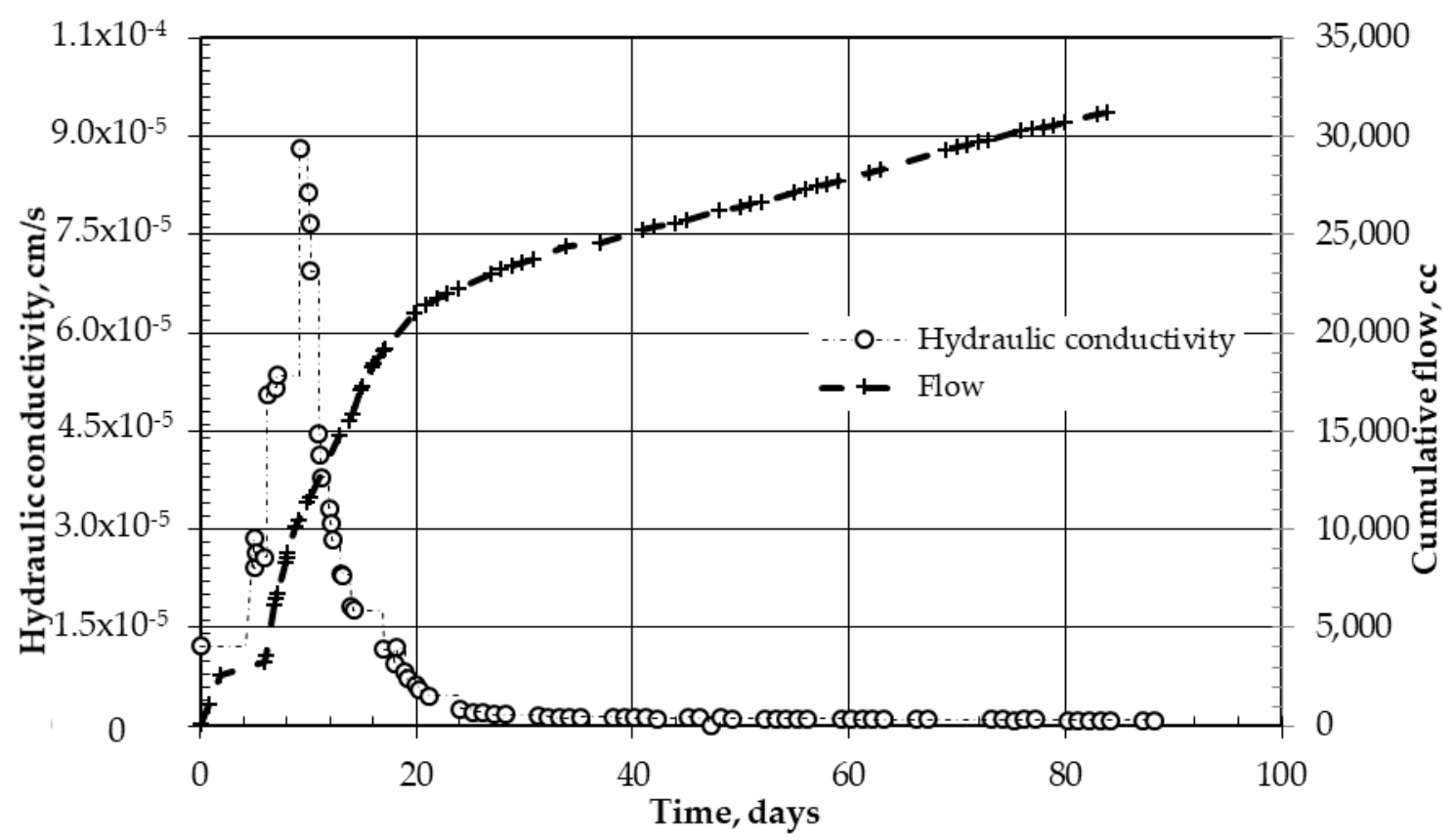

Figure 6. The hydraulic conductivity and cumulative flow versus time in days for $15 \%$ Al-Qatif mixture under $7 \mathrm{kPa}$ mixture.

It can be shown that an overall reduction in the hydraulic conductivity will occur at a later stage after an initial period of increase and decrease in the hydraulic conductivity. The reduction is due to settlement and compression in the sand-clay mixture.

\subsection{The Fines Content}

Figure 7 shows the fine percent before and after extended time hydraulic conductivity tests for four specimens; three mixtures under surcharge stress of $7 \mathrm{kPa}$ and one mixture under the stress of $30 \mathrm{kPa}$. The results indicate a notable reduction in fine percent at the end of the test. The mixture of $15 \%$ Al-Qatif clay showed the highest reduction in fines percent while the mixtures of $15 \%$ bentonite showed the smallest reduction. It can be stated that the loss of fines will be lower for clays of higher plasticity. The application of vertical stress of $30 \mathrm{kPa}$ was found to help stability and control the loss of fines.

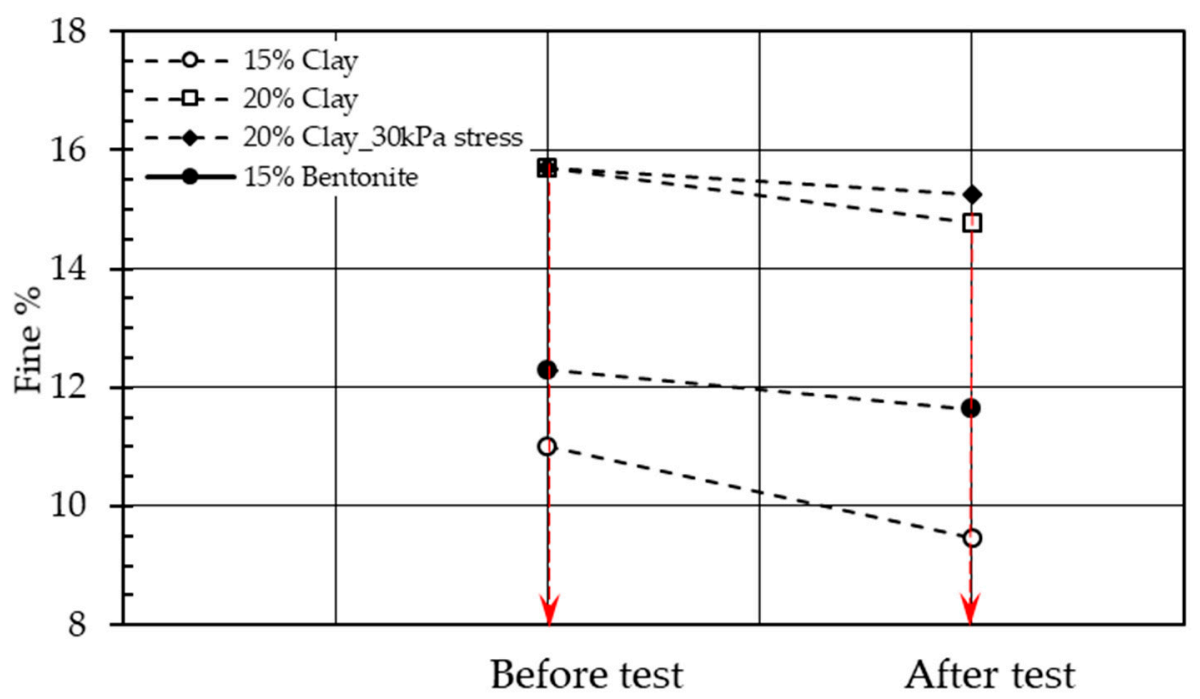

Figure 7. Fine percent before and after extended time hydraulic conductivity tests for different mixtures. 


\subsection{The Ambient Temperature}

An unusual trend occurred during two periods due to temperature changes, the hydraulic conductivity replotted in line with the associated temperature in Figure 8a,b for $15 \%$ bentonite and $20 \%$ clay, respectively. The first period is from 130 days to 200 days and the second period is from 250 days to 270 days. These two periods feautured an increase in hydraulic conductivity. The reason for that is the change in the ambient temperature during these periods. At 130 days, the temperature started to increase from 25 degrees to 27 degrees and then dropped to 20 degrees at about 200 days.
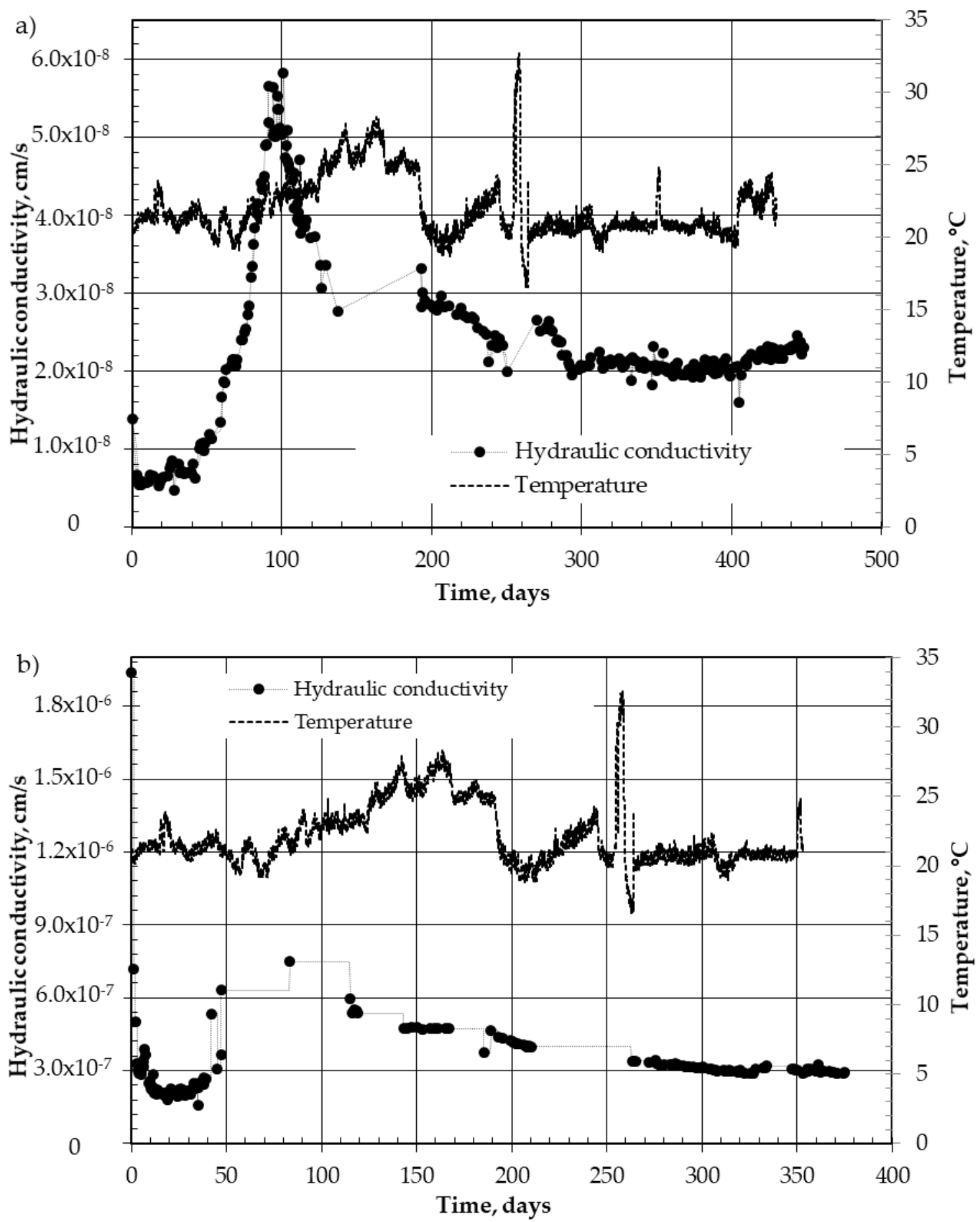

Figure 8. Hydraulic conductivity with associated temperature versus time in days for (a) $15 \%$ bentonite and (b) $20 \%$ clay mixtures. 
The influence of temperature for the 20\% Al-Qatif clay mixture under the surcharge of $30 \mathrm{kPa}$ did show a very minor change during the same two periods noted for the $15 \%$ bentonite clay (130 to 200 days) and ( 250 to 270 days). The expansion coefficients of clays with different mineralogy and different state of stress are expected to be of different magnitude. It is not clear which parameter is having more influence on the hydraulic conductivity changes (Figures 5 and 6).

\subsection{The Applied Stress}

The effect of the applied stress is very clear on the hydraulic conductivity of sand-clay mixtures. The more stresses applied the fewer voids within the mixture. The passways for the flow become smaller in size and the hydraulic conductivity reduction is understood. The collapse of the clay fabric and the consolidation of the mixture are direct results of higher stresses. Comparing Figures 4 and 6 for the 150-day measurements, the hydraulic conductivity is reduced by more than two orders of magnitude $\left(5 \times 10^{-7}\right.$ to $\left.0.2 \times 10^{-5} \mathrm{~cm} / \mathrm{s}\right)$.

\section{Discussion}

The assessment of a liner performance based on the fines content or fines migration can be of good potential to monitor liners over an extended lifetime. The application of continuous flow-through sand-clay mixtures enabled the recognition of phases and patterns of hydraulic conductivity. The influence of the ambient temperature, applied pressure, and the state of flow determine the increase and decrease of the hydraulic conductivity and whether the liner will remain functional as per the proposed design. Investigations of field hydraulic conductivity are often conducted to confirm that the clay sand liner satisfies the required specifications. Daniel [28] discussed the field hydraulic conductivity for a site in Texas using large-scale tests on test pads. It was shown that the hydraulic conductivity decreases with the increase of the liner thickness level of compaction. These tests are usually carried out one time and not at different occasions to see the changes over time. Studies using numerical flow analysis assume conservation of mass and fabric and use the governing equation of one-dimensional unsaturated flow to compute the hydraulic conductivity (U.S. Environmental Protection Agency [29]). These mathematical studies in most cases do not consider the mass changes, erosion, and changes that take place due to temperature, pressure and environmental changes. The theoretical study's limitation makes the current research of interest and significance.

The results obtained in this study confirmed the reduction in the hydraulic conductivity values but after a period of an increase. The period of increase is related the time needed for the inundation of the clay. It can be seen for the natural clay, the increase is very significant and may exceed the design limits. The drop in the hydraulic conductivity over extended periods is found more for the commercial bentonite compared to the natural clay used.

The wash-out of fines was found more significant in the natural clay and this may be attributed to lower bonds between clay particles and adhesive forces holding the particles together.

The outcome of this study with regard to temperature changes is not different from what is reported in the literature. Cho et al. [30] stated that the hydraulic conductivities of bentonites at the temperature of $80{ }^{\circ} \mathrm{C}$ increase up to about 3 times as high as those at $20^{\circ} \mathrm{C}$. The magnitude of changes varies following the placement conditions, state of stress, and the mineralogy of the clay. Applied stresses do have a clear influence on hydraulic conductivity. The collapse of the clay fabric and the consolidation of the mixtures are the direct results of higher stresses. This leads to a decrease in hydraulic conductivity. Higher stresses used in this research resulted in lower hydraulic conductivity.

Other influence on the liners includes chemical interaction. Several studies have confirmed that the hydraulic conductivity and the stability of sand-bentonite mixture degraded with time when permeated with chemical instead of distilled water [31-33]. 
Future works can address a procedure to predict the time required for the hydraulic conductivity to get stabilized and start dropping. The test results presented in this research covered commercial bentonite and natural highly plastic clay. These results and trends can be compared or used for the prediction of similar materials only.

\section{Conclusions}

This study shows that an overall reduction in the hydraulic conductivity of claysand mixtures will occur at a later stage after an initial period of increase and decrease in hydraulic conductivity. The reduction is due to settlement and compression in the sand-clay mixture. The main parameters found to influence the hydraulic conductivity are the loss of fines, the ambient temperature, and the vertical stresses applied. The loss of fines is found lower for clays with higher plasticity. The expansion coefficients of clays with different mineralogy and different state of stress are different and this is reflected in the hydraulic conductivity when the temperature is increased or decreased. The hydraulic conductivity can be reduced by more than two orders of magnitude $\left(5 \times 10^{-7}\right.$ to $\left.0.2 \times 10^{-5}\right)$ when the applied stresses on Al-Qatif clay-sand mixture are increased from $7 \mathrm{kPA}$ to $30 \mathrm{kPa}$. The works presented in this study highlighted the rise and fall phenomenon of the hydraulic conductivity before a continuous drop is established.

Author Contributions: Conceptualization, A.M.A.-M. and M.D.; methodolgy, A.M.A.-M.; formal analysis, A.M.A.-M., M.D. and M.A.A.-S.; investigation, A.M.A.-M. and A.S.; resources; M.A.A.S.; writing-original draft, M.D., A.M.A.-M.; writing-review and editing M.A.A.-S.; supervision, A.M.A.-M. and M.D.; funding acquisition, M.A.A.-S. All authors have read and agreed to the published version of the manuscript.

Funding: Deanship of Scientific Research at King Saud University. Grant reference: Vice Deanship of Scientific Research Chairs, BRCES.

Data Availability Statement: The data used to support the findings of this study are included in the introduced figures.

Acknowledgments: The authors are grateful to the Deanship of Scientific Research, King Saud University, for funding through Vice Deanship of Scientific Research Chairs.

Conflicts of Interest: The authors declare no conflict of interest.

\section{References}

1. Daniel, D.E. Predicting hydraulic conductivity of clay liners. J. Geotech. Eng. Div. ASCE 1984, 110, 285-300. [CrossRef]

2. Chapuis, R.P. Sand-bentonite liners: Predicting permeability from laboratory tests. Can. Geotech. J. 1990, 27, 47-57. [CrossRef]

3. Kenney, T.C.; van Veen, W.A.; Swallow, M.A.; Sungaila, M.A. Hydraulic conductivity of compacted bentonite-sand mixture. Can. Geotech. J. 1992, 29, 364-374. [CrossRef]

4. Sällfors, G.; Öberg-Högsta, A.L. Determination of hydraulic conductivity of sand-bentonite mixtures for engineering purposes. Geotech. Geol. Eng. 2002, 20, 65-80. [CrossRef]

5. Cui, Y.J.; Tang, A.M.; Loiseau, C.; Delage, P. Determining the unsaturated hydraulic conductivity of a compacted sand-bentonite mixture under constant-volume and free-swell conditions. Phys. Chem. Earth A/B/C 2008, 33 (Suppl. 1), 462-471. [CrossRef]

6. Obrike, E.; Osadebe, C.C.; Omoniyi, S.S. Geotechnical analysis of two Nigerian soils for use as clay liners. Bull. Eng. Geol. Environ. 2009, 68, 417-419. [CrossRef]

7. Dafalla, M.A. Efficiency of Sand Clay Liners in Controlling Subsurface Water Flow. In Engineering Geology for Society and Territory-Volume 3: River Basins, Reservoir Sedimentation and Water Resources; Springer: Cham, Switzerland, 2014; pp. 497-499.

8. Abdolahzadeh, A.M.; Lacroix Vachon, B.; Cabral, A.R. Evaluation of the effectiveness of a cover with capillary barrier effect to control percolation into a waste disposal facility. Can. Geotech. J. 2011, 48, 996-1009. [CrossRef]

9. Chapuis, R. Sand-bentonite liners: Field control methods. Can. Geotech. J. 2011, 27, 216-223. [CrossRef]

10. Belkhatir, M.; Schanz, T.; Arab, A. Effect of fines content and void ratio on the saturated hydraulic conductivity and undrained shear strength of sand-silt mixtures. Environ. Earth Sci. 2013, 70, 2469-2479. [CrossRef]

11. Wang, Q.; Cui, Y.; Tang, A.M.; Barnichon, J.; Saba, S.; Ye, W. Hydraulic conductivity and microstructure changes of compacted bentonite/sand mixture during hydration. Eng. Geol. 2013, 164, 67-76. [CrossRef]

12. Al-Mahbashi, A.M.; Dafalla, M. Impact of placement and field conditions on hydraulic conductivity and lifetime of liners. J. Saud Univ. Sci. 2021, 33, 101410, ISSN 1018-3647. [CrossRef] 
13. ASTM D2487-17, Standard Practice for Classification of Soils for Engineering Purposes (Unified Soil Classification System); ASTM International: West Conshohocken, PA, USA, 2017. Available online: www.astm.org (accessed on 13 July 2021). [CrossRef]

14. Rafi, A. Engineering Properties and Mineralogical Composition of Expansive Clays in Al-Qatif Area. Doctoral Dissertation, KFUPM, Dhahran, Saudi Arabia, 1988. [CrossRef]

15. Abduljauwad, S.N.; Al-Sulaimani, G.J. Determination Of Swell Potential Of Al-qatif Clay. Geotech. Test. J. Astm 1993, 16, $469-484$. [CrossRef]

16. Al-Mahbashi, A.M. Soil Water Characteristic Curves of Treated and Untreated Highly Expansive Soil Subjected to Different Stresses. Master's Thesis, Dept. of Civil Engineering, King Saud Univ, Riyadh, Saudi Arabia, 2014.

17. Al-Mahbashi, A.M.; Elkady, T.Y.; Alrefeai, T.O. Soil Water Characteristic Curve and Improvement in Lime Treated Expansive Soil. Geomech. Eng. 2015, 8, 687-706. [CrossRef]

18. Elkady, T.Y.; Al-Mahbasi, A.; Dafalla, M.; Al-Shamrani, M. Effect of compaction state on the soil water characteristic curves of sand-natural expansive clay mixtures. Eur. J. Environ. Civ. Eng. 2017, 21, 289-302. [CrossRef]

19. Elkady, T.Y.; Al-Mahbashi, A.M. Effect of solute concentration on the volume change and shear strength of compacted natural expansive clay. Environ. Earth Sci. 2017, 76, 483. [CrossRef]

20. ASTM D7928. Standard Test Method for Particle-Size Distribution (Gradation) of Fine-Grained Soils Using the Sedimentation (Hydrometer) Analysis: ASTM International: West Conshohocken, PA, USA, 2017. Available online: www.astm.org (accessed on 13 July 2021).

21. ASTM D698. Standard Test Methods for Laboratory Compaction Characteristics of Soil Using Standard Effort (12 $400 \mathrm{ft}-\mathrm{lbf} / \mathrm{ft} 3$ (600 kNm/ m3)); ASTM International: West Conshohocken, PA, USA, 2000; Volume 4.08.

22. ASTM D5856. Standard Test Method for Measurement of Hydraulic Conductivity of Porous Material Using a Rigid-Wall, Compaction-Mold Permeameter; ASTM International: West Conshohocken, PA, USA, 1995. Available online: www.astm.org (accessed on 13 July 2021).

23. ASTM D1140. Standard Test Methods for Determining the Amount of Material Finer than 75- $\mu m$ (No. 200) Sieve in Soils by Washing; ASTM International: West Conshohocken, PA, USA, 2017. Available online: www.astm.org (accessed on 13 July 2021).

24. Gray, D.H.; Rex, R.W. Formation Damage in Sandstones Caused by Clay Dispersion and Migration. Clays Clay Miner. 1996, 14, 355. [CrossRef]

25. Sharma, M.M.; Yortsos, Y.C. Fines Migration in Porous Media. AIChE J. 1987, 33, 1654. [CrossRef]

26. Marot, D.; Bendahmane, F.; Rosquoët, F.; Alexis, A. Internal flow effects on isotropic confined sand-clay mixtures. Soil Sediment Contam. 2009, 18, 294-306. [CrossRef]

27. Marot, D.; Le, V.D.; Garnier, J.; Thorel, L.; Audrain, P. Study of scale effect in an internal erosion mechanism: Centrifuge model and energy analysis. Eur. J.Environ.Civ. Eng. 2012, 16, 1-19. [CrossRef]

28. Daniel, D.E. Case Histories of Compacted Clay Liners and Covers for Waste Disposal Facilities. International Conference on Case Histories in Geotechnical Engineering. 2. 1993. Available online: https://scholarsmine.mst.edu/icchge/3icchge/3icchgesession15/2 (accessed on 13 July 2021).

29. U.S. Environmental Protection Agency. Procedures for Modeling Flow through Clay Liners to Determine Required Liner Thickness; Technical Resource Document for Public Comment; BiblioGov publisher: Washington, DC, USA, 2013; ISBN 13:978-1289177799.

30. Cho, W.J.; Lee, J.O.; Chun, K.S. Influence of temperature on hydraulic conductivity in compacted bentonite. MRS Online Proc. Libr. (OPL) 1997, 506. [CrossRef]

31. Gipson, A.H. Hydraulic Barriers in Soil and Rock; ASTM International: West Conshohocken, PA, USA, 1985. [CrossRef]

32. Shackelford, C.D. Waste-soil interactions that alter hydraulic conductivity. In Hydraulic Conductivity and Waste Contaminant Transport in Soil, ASTM STP 1142; Ddaniel, E., Trautwein, S.J., Eds.; ASTM: West Conshohoken, PA, USA, $1994 ;$ pp. 111-168.

33. Gleason, M.H.; Daniel, D.E.; Eykholt, G.R. Calcuim and sodium bentonite for hydraulic containment applications. J. Geotech. Geoenviron. Eng. ASCE 1997, 123, 438-445. [CrossRef] 